\title{
A NEW SPECIES AND A NEW COMBINATION IN THE AFROALPINE SENECIO NANUS-S. SCHULTZII COMPLEX (ASTERACEAE, SENECIONEAE)
}

\author{
SANTIAGO ORTIZ \& JOSE LUIS VIVERO POL \\ Departamento de Bioloxía Vexetal, Laboratorio de Botánica, Facultade de Farmacia, \\ Universidade de Santiago, 15782 Santiago de Compostela, Galicia, Spain; \\ e-mail: bvsortiz@usc.es
}

\begin{abstract}
SUMMARY
We describe the new species Senecio balensis and propose a new nomenclatural combination Senecio schultzii subsp. chillaloense within the afroalpine Senecio nanus-S. schultzii complex from Ethiopia. Senecio schultzii var. lanatus is assigned to this subspecies.
\end{abstract}

Key words: Senecio, Asteraceae, Senecioneae, Ethiopia, taxonomy.

\section{INTRODUCTION}

The afroalpine species of Senecio L. (Asteraceae, Senecioneae) include a small group of perennial herbs endemic to Ethiopia, characterized by their small size (generally less than $30 \mathrm{~cm}$ tall), including Senecio nanus Sch.Bip. ex A. Rich., S. schultzii Hochst. ex A. Rich. and S. unionis Sch.Bip. ex A. Rich. The latter is very different from the others, in its often conspicuously pinnatifid leaves and small capitula (less than 2.5 $\mathrm{cm}$ wide at anthesis).

Although the typical individuals of $S$. nanus and $S$. schultzii are very different, these species are morphologically similar, and indeed it can sometimes be difficult to distinguish them.

In November 2001 we made a collection trip from Lalibela to the peak of Mt Guli Bamba in the Abune Yosef Mountains (Welo, Ethiopia), and collected material of those two species at the afroalpine level (altitude over $4000 \mathrm{~m}$ ). When we compared this material with material from other afroalpine areas of Ethiopia, we found marked and consistent morphological differences between northern and southern populations of this species complex, located in the two Ethiopian afroalpine centres of biodiversity and endemism identified by Hedberg (1994). In view of our findings we describe the new species Senecio balensis and propose a new nomenclatural combination.

\section{MATERIAL AND METHODS}

This study was based on morphological analysis of specimens from BM, ETH, K, P, and UPS (abbreviations accounting to Holmgren et al., 1990). The material was studied with the aid of a light microscope. 


\section{IDENTIFICATION KEY FOR THE SENECIO NANUS-S. SCHULTZII COMPLEX}

1a. Plant 15-30(-60) cm high. Leaves usually hispid-pubescent, entirely green, 2-25 mm wide, generally with serrate-crenate margins. Phyllaries and achenes hairy. 3

b. Plant 3-10 cm high. Leaves glabrous or glabrescent, purple or pink at the base, $1.2-7 \mathrm{~mm}$ wide, margins entire or very sparsely and indistinctly denticulate. Phyllaries and achenes glabrous . . . . . . . . . . . . . . 2

2a. Capitula broadly cylindrical; bracts of the calyculus $4-6 \mathrm{~mm}$ long, situated at the base of the capitulum and not reaching the upper half of the involucre; involucre 9-11 mm wide; c. 13 (12-16) phyllaries per capitulum, 5-6(-7) mm long. Ray floret limb 5-7 mm long. Pappus $4-4.5 \mathrm{~mm}$ long . . . . . . . . Senecio nanus

b. Capitula broadly obconic to campanulate; bracts of the calyculus (3-)6-12 $\mathrm{mm}$ long, sparsely scattered along distal portion of the peduncle, the longest reaching to the upper half of the involucre; involucre c. 21 (15-25) mm wide; 20-24 phyllaries per capitulum, (6-) 10-12 mm long. Ray floret limb 6-12 mm long. Pappus

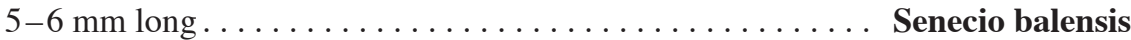

3a. Leaves serrate, often slightly. Capitula generally obconic, \pm congested, on erect peduncles; bracts of the calyculus and phyllaries with a greenish or slightly blackish apex, acute to acuminate. Ray floret limb 6-12 mm long, light yellow . . . . .

S. schultzii subsp. schultzii

b. Leaves serrate-crenate, often conspicuously. Capitula campanulate to hemispheric, lax, on erect-patent peduncles; bracts of the calyculus and phyllaries with a conspicuous blackish apex, subacute to obtuse. Ray floret limb 12-16 mm long, dark

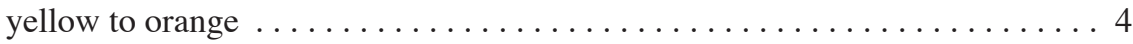

4a. Leaves, stems and phyllaries sparsely to densely pubescent

S. schultzii subsp. chillaloense var. chillaloense

b. Leaves, stems and phyllaries thinly to densely white tomentose to woolly ......

S. schultzii subsp. chillaloense var. lanatus

Senecio balensis S. Ortiz \& Vivero, spec. nov. - Fig. 1

A Senecio nanus Sch.Bip. ex A. Rich., simili, capitulis late obconicis, calyculi bracteis longioribus ((3-)6-12 mm longis, ita ut nonnumquam 1/2 involucri superetur ab eis), involucro latiore (15-25 mm lato), involucri bracteis numerosioribus (20-24) atque longioribus ((6-)10-12 mm longis), radiatis floribus longioribus (6-12 mm longis) pappisque item longioribus (5-6 mm longis) differt. - Typus: Sue Edwards 71 (holo ETH; iso K), Ethiopia, Bale, south of Bale plateau, lava flow, steep valleys with very large boulders and flat areas on top with little soil, $3930 \mathrm{~m}$ alt., 6 Nov. 1971.

Perennial herb, 3-10 cm tall, caespitose, rhizomatous with thick rootstock, almost entirely glabrous. Leaves $30-110$ by $1.2-2.5(-4) \mathrm{mm}$, basal, greenish, glabrous to glabrescent, slightly fleshy, linear, somewhat broader at the base where they are subamplexicaul and tinged with purple, margins entire or very sparsely and indistinctly denticulate, apex rounded. Capitula radiate, solitary, terminal, peduncle 3-10 mm long, arising from leaf rosette, with bracts similar to the leaves but shorter and with a more acute apex, especially those situated near the capitulum. Calyculus of linear-lanceolate bracts (3-) $6-12$ by $0.7-1.5 \mathrm{~mm}$, sparsely distributed along the apical part of the peduncle and reaching the upper half of the involucre, glabrous or woolly at the base, 

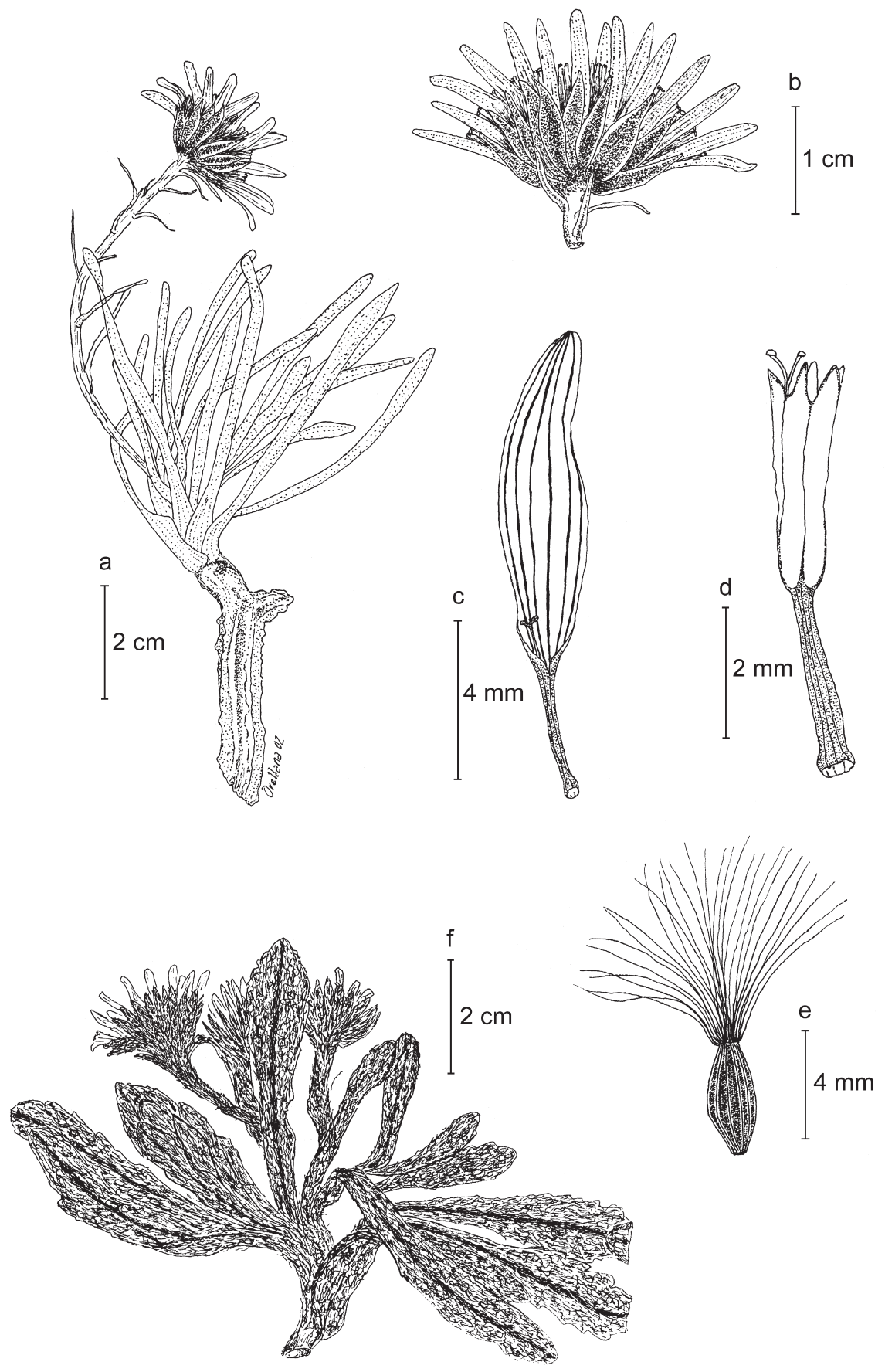

Fig. 1. a-e: Senecio balensis S. Ortiz \& Vivero. a. Habit; b. capitulum; c. ray floret; d. disc floret; e. achene with pappus (Evans \& Hiller 332 (ETH)). - f: Senecio schultzii subsp. chillaloensis var. lanatus Otieno \& Mesfin. Habit (G. \& S. Miehe 87). Drawn by Luis G. Orellana. 
apex often ciliolate and often blackish, rarely with marginal glandular hairs. Involucre (8-) 10-12(-15) by $15-25 \mathrm{~mm}$, broadly obconic, with $20-24$ phyllaries. Phyllaries (6-) $10-12$ by $0.8-2(-3) \mathrm{mm}$, linear-lanceolate, acute, green, glabrous, apex ciliolate and often blackish. Ray florets yellow, tube $3-4$ by $0.5 \mathrm{~mm}$, limb $6-12$ by $1.5-3 \mathrm{~mm}$, 4 or 5 striate, apex 2- or 3-fid. Disc florets yellow, tube c. 5 by $0.5-1 \mathrm{~mm}$, apical lobes 0.5-1 mm. Cypselae $2-3$ by $0.3-0.5 \mathrm{~mm}$, ellipsoid to cylindric, c. 10-ribbed, glabrous. Pappus of almost smooth to very slightly scabrid bristles, 5-6 mm long.

Note - Senecio balensis can be distinguished from $S$. nanus by calyculus, involucre, flower and pappus morphology. It occurs in afroalpine areas in central and southern Ethiopia, in the provinces of Gojam and Bale, while S. nanus occurs in the northern provinces of Gonder and Welo.

Additional specimens examined:

ETHIOPIA. Bale: Bale Mountains National Park, on the crest of Garba Goracha camp-site, $6^{\circ} 51^{\prime}-$ $7^{\circ} 10^{\prime} \mathrm{N}, 39^{\circ} 41^{\prime}-48^{\prime} \mathrm{E}, 4100 \mathrm{~m}$ alt., along a shallow lakelet, 2 Nov. 1973, O. Hedberg 5639 (ETH); Wasama, Tullu, Hadj Ahmad, 6 55' N, 39 46' E, 3980 m alt., afroalpine Festuca-Pentaschistis grasslands on shallow and seasonally waterlogged soils, 7 Jan. 1990, G. \& S. Miehe 595 (ETH). Gojam: Choké Mts, upper Godeb valley, below Mt Birham, $12750 \mathrm{ft}$ alt., wet rock platform, 28 Aug. 1957, Evans \& Hiller 332 (BM, ETH, K).

Senecio schultzii Hochst. ex A. Rich. subsp. chillaloensis (Cufod. ex Hedberg) S. Ortiz \& Vivero, comb. \& stat nov.

Basionym: Senecio chillaloensis Cufod. ex Hedberg (1971) 119. - Type: O. Hedberg 4214 (holo UPS; iso AA, EA), Ethiopia, Arsi, Chillalo Awraja, Galama Mt, about $3 \mathrm{~km}$ E of Boraluco, 3750 m alt., 8 Sept. 1967.

This taxon can be distinguished from the type subspecies, S. schultzii subsp. schultzii, by several characters, as indicated in the key. Subsp. schultzii occurs in afroalpine territories of north and central Ethiopia, whereas subsp. chillaloensis occurs largely in central and southern territories. Hedberg (1971) describes these latter populations as a distinct species, which he attributes to Cufodontis. However, some populations in the southern part of the northern province of Gonder show intermediate characters between subsp. chillaloensis and subsp. schultzii (Schimper 1531, Thomerson 579). Intermediate morphology is also observed in certain populations in Bale province (Mesfin Tadesse 7836). We therefore consider the rank of subspecies to be more appropriate for the southern populations.

Senecio schultzii Hochst. ex A. Rich. subsp. chillaloensis (Cufod. ex Hedberg) S. Ortiz \& Vivero var. lanatus Otieno \& Mesfin

Senecio schultzii Hochst. ex A. Rich. subsp. chillaloensis (Cufod. ex Hedberg) S. Ortiz \& Vivero var. lanatus Otieno \& Mesfin in Tadesse (1999) 30. - Type: Mooney 8332 (holo ETH; iso K), Ethiopia, Bale, Batu, 17 Dec. 1959.

This variety is characterized by its thinly to densely white tomentose to woolly leaves, stems and phyllaries, and is only known from afroalpine meadows in the Bale Mountains at altitudes between 3900 and 4375 m (Tadesse, 1999). This variety should be subordinated to subsp. chillaloensis since it has conspicuously serrate-crenate leaves, together with lax, campanulate capitula on erect-patent peduncles, and ray-florets longer than $12 \mathrm{~mm}$. 


\section{ACKNOWLEDGEMENTS}

Our thanks go to the curators of the herbaria housing the material studied for this paper, to Ensermu Kelbessa for his kind assistance during our study of the ETH material in Addis Ababa, to Mesfin Tadesse for his help during the preparation of this paper, to Manuel Laínz for the Latin diagnosis, to Luis G. Orellana for the illustrations, and to Guy Norman for the English translation.

\section{REFERENCES}

Hedberg, O. 1971. The high mountain flora of the Galama Mountain in Arussi Province, Ethiopia. Webbia 26: 101-128.

Hedberg, O. 1994. Afroalpine centres of biodiversity and endemism. In: J.H. Seyani \& A.C. Chikuni (eds.), Proceedings of the XIIIth Plenary Meeting of AETFAT, vol. 2: 877-882, Malawi.

Holmgren, P.K., N.H. Holmgren \& L.C. Barnett. 1990. Index Herbariorum. I. The Herbaria of the World, 8th ed. Regnum Veg. 120. New York Botanical Garden.

Tadesse, M. 1999. New combinations, varieties and synonyms in African Compositae. Compositae Newslett. 33: 23-32.

\section{IDENTIFICATION LIST}

sch $=S$. schultzii Hochst. ex A. Rich. subsp. schultzii var. schultzii

lan $=$ S. schultzii Hochst. ex A. Rich. subsp. schultzii var. lanatus Otieno \& Mesfin

Evans \& Hiller 556: sch.

Friis, Gilbert \& Vollesen 3424: sch.

Hedberg 5534b: sch.

Miehe, G. \& S. 87: lan; 89: sch; 90: sch.

Pavlov \& Petelin 192: sch.

Schimper 1524: sch; 1531: sch - Scott 138: sch.

Thomerson 579: sch - Thulin 1666: sch. 